\title{
急性膿胸に対する胸腔鏡手術における 術後在院期間に関与する因子の検討
}

宮原 栄治, 川㟝由香里, 木村 厚雄, 奥道 恒夫

要 旨

急性膿胸 22 症例を対象として胸腔鏡下膿胸腔择爬術の術後在院期間に影響する因子を検討した．飲酒歴・術前合併症・ 術前ドレナージ留置の有無，膿胸腔排液の細菌培養陽性陰性，において有意差は認めなかった。また，年齡，BMI，哭煙指 数, 手術時間, 術中出血量との間に有意な相関は認められなかった. 術前抒よび術後 1 週目の Alb2.5 g/dl 未満の症例では以 上の症例に比較し，術後在院期間が有意に延長していた。また，症状発現から手術，医療機関受診から当科紹介の各期間と 術後在院期間との間には正の相関を認め, 症状出現から手術までの期間が 23 日未満の症例は以上の症例に比較し，また医療 機関受診から当科受診までの期間が 15 日未満の症例は以上の症例に比較し, 術後在院期間が有意に短縮していた. 膿胸診断 時は，保存治療開始早期に (3 日目を目処に) 炎症反応の低下を認めなければ外科治療を考慮することが重要と考えられた.

索引用語：急性膿胸，胸腔鏡下膿胸垫择爬術，術後在院期間，血清アルブミン值 acute empyema, thoracoscopic surgery, postoperative hospitalization period, serum albumin

\section{はじめに}

急性膿胸はまずドレナージおよび抗生剤投与による保 存的治療が行われ，保存的治療が奏功しない場合は早期 の外科的介入が必要となる. 急性膿胸に対する胸腔鏡手 術の有用性はHutter らにより報告され ${ }^{1)}$ ，早期の介入に より術後合併症や入院期間における有用性が報告されて いる ${ }^{2 \cdot 7}$ ．急性膿胸に対する胸腔鏡手術の術後在院期間に 影響する因子を検討した.

\section{対象および方法}

2014 年 2 月から 2017 年 3 月まで当院で手術を施行し た膿胸症例は 29 例であった。 そのうち, 悪性腫瘍, 結核, 非結核性抗酸菌症, 術後気管支瘦による有㾞性膿胸を除 いた急性膿胸 22 症例（すべて他院からの紹介）を対象に 検討した。

国家公務員共済組合連合会吉島病院呼吸器センター呼吸器外 科

原稿受付 2017 年 8 月 25日

原稿採択２017年10月15日
手術適応は，3 日間以上の抗生剤投与またはドレナー ジ施行後も肺膨張や炎症反応の改善が不良な症例, 膿胸 腔が多房化しドレナージが無効な症例とした．全例に胸 腔鏡下膿胸腔掻爬術, 癒着剥離術を行った. 手術は 3 ポー トで行い，胸腔鏡下に膿胸腔を搔爬し被包化された膿汁 を除去した，虚脱した肺を再膨張させるため，胸壁との 癒着は可能な限り剥離した。器質化期の症例においては 臟側胸膜上の肥厚した peel を肺瘦が生じない程度に剥 離し再膨張が得られるようにした．24 Fr ブレイクド レーンを留置し, 術後は $-4 \mathrm{cmH}_{2} \mathrm{O}$ で持続吸引し, エア リークがなく排液量が $50 \mathrm{ml} /$ 日以下で抜去した。

統計学的検討は, 統計ソフト EZR を用いて, 平均值の 検定はStudent's t-testで，2群の比率の検定はChi square test で, 相関係数の検定は Pearson の積率相関係 数で行い, 有意水準は $5 \%$ 以下とした.

\section{結 果}

平均年齢は 66.3 歳，男性 20 例，女性 2 例，右側 14 例，左側 8 例であった。喫煙者 20 例（すべて男性），術 前合併症は, 心房細動 5 例, 脳梗塞 5 例, 糖尿病 4 例, 
Table 1 Clinical factors and postoperative hospitalization period

\begin{tabular}{lccc}
\hline \multicolumn{1}{c}{ Clinical factor } & PHP (day) & SD & P-value \\
\hline never drinking $(\mathrm{n}=14)$ & 21.3 & 7.46 & 0.633 \\
drinking $(\mathrm{n}=8)$ & 19.3 & 11.0 & \\
no preoperative complications $(\mathrm{n}=6)$ & 21.4 & 9.50 & 0.471 \\
preoperative complications $(\mathrm{n}=16)$ & 18.3 & 6.37 & \\
no preoperative drainage $(\mathrm{n}=8)$ & 18.5 & 8.86 & 0.409 \\
preoperative drainage $(\mathrm{n}=14)$ & 21.7 & 8.75 & \\
negative bacterial culture $(\mathrm{n}=18)$ & 19.7 & 8.96 & 0.334 \\
positive bacterial culture $(\mathrm{n}=4)$ & 24.5 & 7.32 & \\
\hline
\end{tabular}

PHP: postoperative hospitalization period

Student's t-test

SD: standard deviation

Table 2 Correlations between clinical factors and postoperative hospitalization period

\begin{tabular}{|c|c|c|c|}
\hline Clinical factor & Average (SD) & $\mathrm{CC}$ & P-value \\
\hline Age (37-91) & $66.3( \pm 14.0)$ & 0.368 & 0.0919 \\
\hline BMI (17.0-25.9) & $21.4( \pm 2.71)$ & 0.0565 & 0.803 \\
\hline Brinkman Index $(0-1,600)$ & $565.0( \pm 383.2)$ & 0.23 & 0.329 \\
\hline Operative time (min) $(80-271)$ & $133.0( \pm 49.3)$ & 0.0288 & 0.899 \\
\hline Blood loss (mL) (30-859) & $224.0( \pm 247.3)$ & 0.157 & 0.485 \\
\hline \multicolumn{4}{|l|}{ Preoperative } \\
\hline WBC $(/ \mu \mathrm{L})(4,466-24,000)$ & $12,870( \pm 5,243)$ & -0.0737 & 0.745 \\
\hline CRP (mg/dL) (3.97-30.2) & $15.8( \pm 8.41)$ & -0.201 & 0.37 \\
\hline Alb (g/dL) (1.8-3.2) & $2.41( \pm 0.416)$ & -0.501 & 0.0176 \\
\hline \multicolumn{4}{|l|}{ One week after surgery } \\
\hline $\mathrm{WBC}(/ \mu \mathrm{L})(4,600-22,000)$ & $8,816( \pm 3,731)$ & -0.131 & 0.56 \\
\hline $\mathrm{CRP}(\mathrm{mg} / \mathrm{dL})(0.5-15)$ & $4.51( \pm 3.08)$ & 0.271 & 0.223 \\
\hline Alb (g/dL) (1.9-3.1) & $2.54( \pm 0.33)$ & -0.485 & 0.0223 \\
\hline Symptom onset to surgery (days) $(7-41)$ & $19.8( \pm 9.33)$ & 0.525 & 0.0121 \\
\hline Symptom onset to medical institution visit (days) (1-15) & $5.44( \pm 3.82)$ & -0.0817 & 0.718 \\
\hline Medical institution visit to consulting our hospital (days) (0-25) & $8.18( \pm 7.78)$ & 0.572 & 0.00542 \\
\hline Consulting our hospital to surgery (days) (1-28) & $6.05( \pm 6.58)$ & 0.122 & 0.59 \\
\hline
\end{tabular}

高血圧 3 例, 心不全 2 例, 関節リウマチにて免疫抑制剤 投与中 1 例, アルコール性肝炎 1 例, また, 85 歳以上の 超高齢者は 3 例であった. 初発症状は, 発熱 11 例, 胸痛 9 例, 息切れ 3 例, 咳嗽 2 例, 食欲低下 1 例であった. 保 存治療開始 3 日目に炎症反応の低下が認められず紹介さ れた症例は 2 例, 1 週間以上炎症反応の低下が認められ ず紹介された症例は 6 例, 膿胸腔多房化にて紹介された 症例は 14 例であった. 術前ドレナージを施行された症例 は 14 例 (63.6\%), ドレナージから手術までの期間は平均 12.1 日であった。
手術時間は平均 133 分, 術中出血は平均 $288 \mathrm{~g}$ であっ た．胸水培養にて起炎菌が同定されたのは 3 例 $(13.6 \%)$ でいずれもStreptococcus milleriであった，術後胸腔ド レーン留置期間は平均 8.1 日 (4-14 日), 術後在院期間は 平均 19.8 日（7-41 日）で再手術症例は認めなかった.

飲酒歴の有無, 術前合併症の有無, 術前ドレナージ留 置の有無, 膿胸腔排液の細菌培養陽性陰性では, 各群間 において術後在院期間に有意差を認めなかった（Table 1). また, 年齢, BMI, 喫煙指数, 手術時間, 術中出血 量と術後在院期間との間に相関を認めなかった（Table 

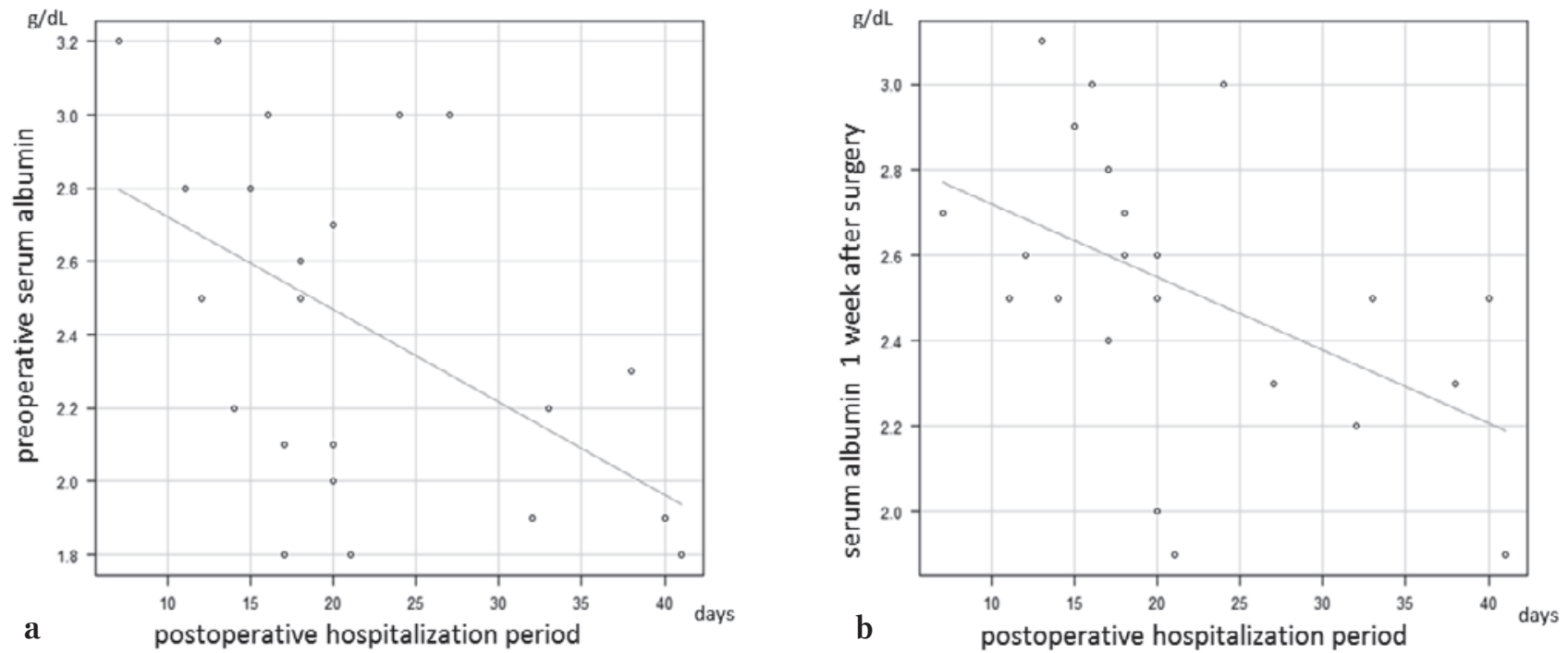

Fig. 1 There was a negative correlation between the postoperative hospitalization period and serum albumin (a) before surgery and (b) one week after surgery.
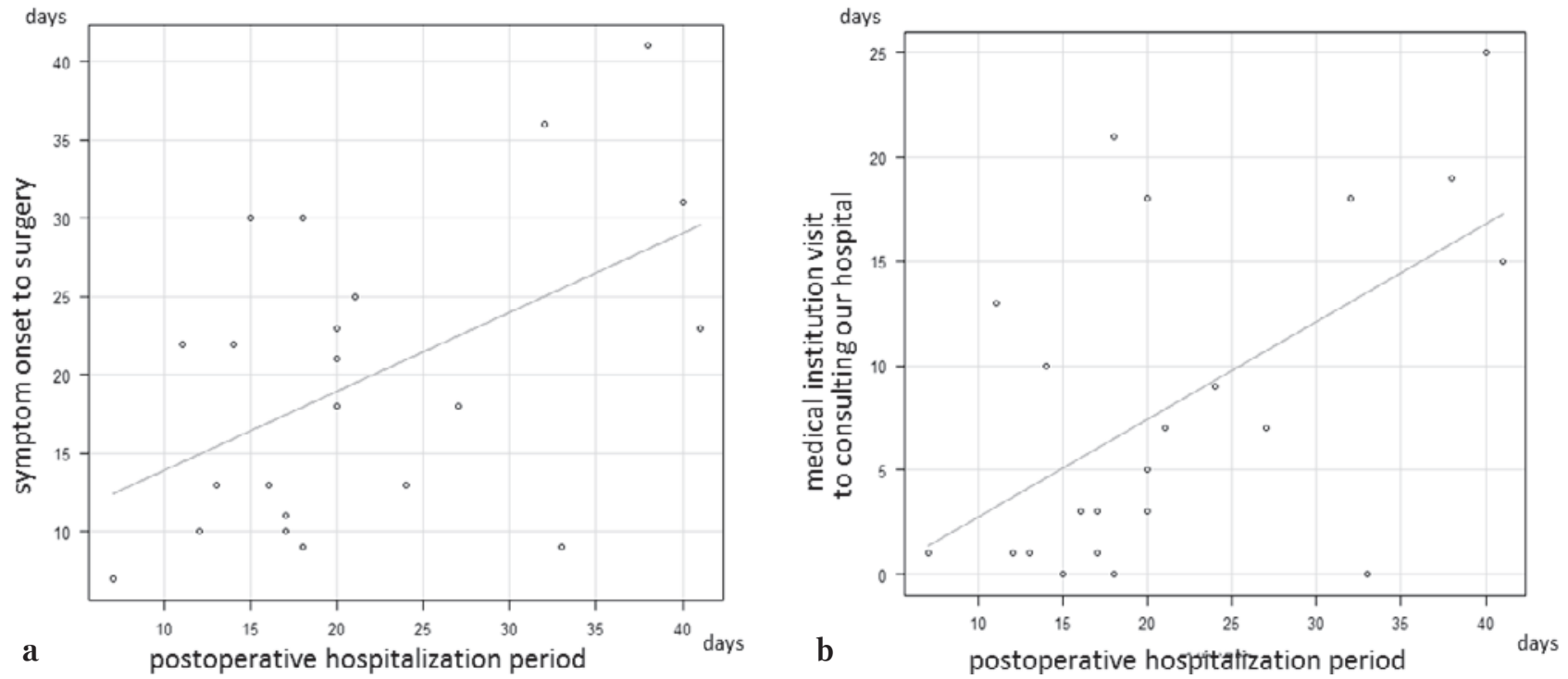

Fig. 2 There was a positive correlation between the postoperative hospitalization period and period (a) from symptom onset to surgery, (b) from medical institution visit to consulting our hospital.

2).

炎症性マーカーとして, 術前および術後 1 週目の白血 球数 - CRP 值 - Alb 值と術後在院期間との相関を解析 した (Table 2). 術前 Alb 值 $(\mathrm{p}=0.0176)$ と術後 1 週目 Alb 值（ $\mathrm{p}=0.0223 ）$ との間には負の相関を認めた（Fig. 1). また症状発現から手術, 症状発現から医療機関受診, 医療機関受診から当科紹介, 当科紹介から手術, の各期 間と, 術後在院期間との相関を解析した (Table 2). 症状
発現から手術 $(p=0.0121)$, 医療機関受診から当科紹介 $(\mathrm{p}=0.00542)$ との間には期間は，正の相関を認めた（Fig. 2).

術後在院期間と有意な相関を認めた因子において cut off 值を検討し, p 值が最小になる cut off 值を設定した. Alb は cut off 值を $2.5 \mathrm{~g} / \mathrm{dl}$ に設定すると, 術前 Alb2.5 g/ $\mathrm{dl}$ 未満の症例では以上の症例に比較し $(\mathrm{p}=0.00375)$ ，ま た, 術後 1 週目 Alb2.5 g/dl 未満の症例では以上の症例に 
Table 3 Correlated factors and the postoperative hospitalization period

\begin{tabular}{lccc}
\hline \multicolumn{1}{c}{ Factors correlated with PHP } & PHP (days) & SD & P-value \\
\hline Preoperative Alb $<2.5 \mathrm{~g} / \mathrm{dL}(\mathrm{n}=11)$ & 25.6 & 8.26 & 0.00375 \\
Preoperative Alb $\geqq 2.5 \mathrm{~g} / \mathrm{dL}(\mathrm{n}=11)$ & 15.5 & 5.98 & \\
One week after surgery Alb $<2.5 \mathrm{~g} / \mathrm{dL}(\mathrm{n}=7)$ & 26.4 & 5.44 & 0.0283 \\
One week after surgery Alb $\geqq 2.5 \mathrm{~g} / \mathrm{dL}(\mathrm{n}=15)$ & 17.8 & 8.75 & \\
Symptom onset to surgery $<23$ days $(\mathrm{n}=14)$ & 17.7 & 6.80 & 0.0113 \\
Symptom onset to surgery $\geqq 23$ days $(\mathrm{n}=8)$ & 28.2 & 10.8 & \multirow{2}{*}{0.00109} \\
Medical institution visit to consulting our hospital $<15$ days $(\mathrm{n}=16)$ & 17.8 & 6.43 & 0.0 .3 \\
Medical institution visit to consulting our hospital $\geqq 15$ days $(\mathrm{n}=6)$ & 31.6 & \multicolumn{3}{c}{ Student's t-test }
\end{tabular}

比較し ( $\mathrm{p}=0.0283)$, 術後在院期間が有意に延長していた. また, 症状出現から手術までの期間の検討では cut off 值を 23 日に設定すると, 23 日未満の症例は以上の症例 に比較し, 術後在院期間が有意に短縮していた（ $\mathrm{p}=$ 0.0113). 医療機関受診から当科受診までの期間の検討で は cut off 值を 15 日に設定すると, 15 日未満の症例は以 上の症例に比較し, 術後在院期間が有意に短縮していた $(\mathrm{p}=0.00109)$ (Table 3).

\section{考察}

急性膿胸に対する胸腔鏡手術の術後在院期間に影響す る因子を検討した。

飲酒歴の有無, 術前合併症の有無, 術前ドレナージ留 置の有無, 膿胸腔排液の細菌培養陽性陰性, において有 意差は認めなかった，術前ドレナージ留置については, その有無で治療成績, 術後合併症に差はなかったと報告 されている8). また, 年齢, BMI, 喫煙指数, 手術時間, 術中出血量, 各因子との間に有意な相関は認めなかった.

炎症マーカーの検討では, 術前および術後 1 週目の Alb 值との間には負の相関を認めた. Alb2.5 g/ dl 未満の 症例では以上の症例に比較し, それぞれ術後在院期間が 有意に延長していた. 術前 Alb2.5 g/dl 以下の症例では術 後合併症が増えるとの報告もあり ${ }^{9)}, \mathrm{Alb} 2.5 \mathrm{~g} / \mathrm{dl}$ は術後 の経過を予測する指標になると考えられた.

症状発現から手術, 医療機関受診から当科紹介の各期 間と術後在院期間との間には正の相関を認めた，症状出 現から手術までの期間が 23 日未満の症例は以上の症例 に比較し，また医療機関受診から当科受診までの期間が 15 日未満の症例は以上の症例に比較し, 術後在院期間が 有意に短縮していた. 本検討では佐藤ら ${ }^{10)}$ の報告に則り， 保存的治療後 3 日目の炎症反応に改善がみられなければ
胸腔鏡手術の方針としたが，この方針で紹介された症例 はわずか 2 例であり, 紹介時すでに保存的治療後 1 週間 を経過した症例を 12 例（54.5\%）に認め，そのうち 6 例は紹介時にも炎症反応が持続していた。このことが, 症状出現から手術までの期間, 中でも医療機関受診から 当科受診までの期間が，術後在院期間に有意に影響した 原因と考えられた.JAID/JSC 感染症治療ガイドライ ン11でも膿胸と診断されたらドレナージおよび抗生剂投 与を行い早期に外科医に相談することを勧めている。治 療期間の短縮, 膿胸再燃の予防のため, ドレナージおよ び抗生剂投与で軽快しない急性膿胸に対しては可能な限 り早期の胸腔鏡手術を行い, る時点で胸腔鏡手術を考慮することが望ましいと報告さ れている ${ }^{12)}$.

術前合併症のある症例や高齢の症例は保存的治療が優 先され術前治療期間が長くなり，また合併症のため術後 入院期間も長期になると考えられる ${ }^{13)}$. 症状発現から手 術までの期間が 23 日未満と 23 日以上の症例で術前合併 症の有無を比較すると, 23 日未満の症例では 9 例中 6 例に, 23 日以上の症例では 13 例中 10 例に術前合併症を 認め, 有意差を認めなかった。 術前合併症の有無にかか わらず，初発から手術までの期間が短ければ術後入院期 間も短縮できると考えられた。

Andrews ら ${ }^{14)}$ は急性膿胸を滲出期, 線維素膿性期, 器 質化期とし，それぞれ発症から 2〜14 日，3〜4週，それ 以降と期間分類している ${ }^{4,5,15)}$. また胸腔鏡手術の良い適 応は線維素膿性期までとされている ${ }^{5.7)}$. 症状出現から手 術までの期間が 23 日未満の症例は線維素膿性期, 以上の 症例は器質化期と考えられ, 両者においてその手術時間 と術中出血量を検討した. 平均手術時間は 23 日未満の症 例で 128.5 分, 以上の症例で 142.1 分, 平均術中出血はそ 
Table 4a The period from symptom onset to surgery and operative time/blood loss

\begin{tabular}{|c|c|c|c|}
\hline & \multicolumn{2}{|c|}{ Symptom onset to surgery } & \multirow{2}{*}{$\mathrm{P}$-value } \\
\hline & $<23$ days & $\geqq 23$ days & \\
\hline Operative time (min) & $128.5 \pm 48.0$ & $142.1 \pm 56.8$ & 0.555 \\
\hline Blood loss (mL) & $290.7 \pm 237.7$ & $283.4 \pm 295.5$ & 0.95 \\
\hline
\end{tabular}

Table 4b Correlation with the period from symptom onset to surgery and preoperative $\mathrm{WBC} / \mathrm{CRP}$

\begin{tabular}{lcc}
\hline & CC & P-value \\
\hline Preoperative WBC $(/ \mu \mathrm{L})$ & -0.508 & 0.0157 \\
Preoperative CRP $(\mathrm{mg} / \mathrm{dL})$ & -0.426 & 0.0482 \\
\hline
\end{tabular}

Pearson's product moment correlation

れぞれ $290.7 \mathrm{ml}$ と $283.4 \mathrm{ml}$ で有意差を認めなかった (Table 4a). 器質化期の手術適応については, 3 週以降は 臓側胸膜が厚い醽膿胸膜で覆われるため, 胸腔鏡手術は 禁忌との報告 ${ }^{5}$ もあるが, 症状発現から手術まで 28 日を 超える症例でも膿胸腔の大部分は線維素膿性所見であ り, 早期の器質化期も胸腔鏡手術の適応との報告もあ $3^{7}$.16). 本検討では, 線維素膿性期と器質化期において手 術時間, 術中出血に有意差を認めなかったが, 術後在院 期間には有意差を認め, 線維素膿性期に胸胿下手術を行 うことの有用性が示唆された，また，器質化期の症例に おいては多房化した膿胸腔を単房化するのみでは肺膨張 は得難いため, 臓側胸膜上の肥厚した peel を肺瘦が生じ ない程度に剥離することで再膨張させ，良好な結果が報 告されている ${ }^{17}$.18). 本検討でも同様な手術操作を行い再手 術症例は認めなかった。

症状出現から手術までの期間と術前白血球数, CRP 值とは負の相関を認めた (Table 4b)，術前抗生剤投与の 期間が長期になれば術前炎症反応が低下していたが，術 前炎症反応の低下と術後在院期間との間に相関を認めな かった (Table 2)，抗生剂投与，ドレナージ等の保存治療 開始後早期に (3 日目を目処に) 炎症反応の低下を認めな ければ外科治療を考慮することが重要と考えられた。

\section{利益相反}

本論文について申告する利益相反はない.

\section{文献}

1. Hutter JA, Harari D, Braimbridge MV. The management of empyema thoracis by thoracoscopy and irrigation. Ann Thorac Surg 1985; 39: 517-20.

2. Lemmer JH, Botham MJ, Orringer MB. Modern management of adult thoracic empyema. J Thorac Cardiovasc Surg 1985; 90: 849-55.

3. Ridley PD, Braimbridge MV. Thoracoscopic debridement and pleural irrigation in the management of empyema thoracis. Ann Thorac Surg 1991; 51: 461-4.

4. Lawrence DR, Ohri SK, Moxon RE, Townsend ER, Fountain SW. Thoracoscopic debridement of empyema thoracis. Ann Thorac Surg 1997; 64: 1448-50.

5. Striffeler H, Gugger M, Im Hof V, Cerny A, Furrer M, Ris HB. Video-assisted thoracoscopic surgery for fibrinopurulent pleural empyema in 67 patients. Ann Thorac Surg 1998; 65: 319-23.

6. 伊東真哉, 高嶋義光, 小林 淳, カレッド レジャード. 急性膿胸に対する胸腔鏡下手術 その至適時期について の考察. 日呼外会誌 2001; 15:555-60.

7. Wozniak CJ, Paull DE, Moezzi JE, Scott RP, Anstadt MP, York VV, et al. Choice of first intervention is related to outcomes in the management of empyema. Ann Thorac Surg 2009; 87: 1525-30.

8. 吉岡 孝, 高尾和志. 胸腔鏡手術を行った急性膿胸症例の 検討. 気管支学 2010; 32: 220-3.

9. 河北直也, 広瀬敏幸, 森下敦司, 住友正幸. 急性膿胸に対 する胸胅鏡下手術 35 例の検討 血清アルブミン值は術 後合併症予測因子となりうる。日呼外会誌 2015; 29: 55965.

10，佐藤長人，星 永進，青山克彦，村井克己，池谷朋彦，杉 田 裕, 他. 急性細菌性膿胸における胸腔鏡治療の検討. 
気管支学 2003; 25: 279-83.

11. 三笠桂一, 青木信樹, 青木洋介, 阿部修一, 岩田 敏, 尾 内一信, 他. JAID/JSC 感染症治療ガイドライン一呼吸器 感染症一. 日化療会誌 2014; 62: 1-109.

12. 持永浩史, 赤嶺晋治, 村岡昌司, 森野茂行. 急性膿胸に対 する治療方針に関する検討. 日呼外会誌 2011; 25: 134-9.

13. Ferguson AD, Prescott RJ, Selkon JB, Watson D, Swinburn CR. The clinical course and management of thoracic empyema. QJM 1996; 89: 285-9.

14. Andrews NC, Parker EF, Shaw RR, Wilson NJ, Webb WR. Management of nontuberculous empyema. A statement of the subcommittee on surgery. Am Rev Respir
Dis 1962; 85: 935-6.

15. Light RW. Parapneumonic effusions and empyema. Proc Am Thorac Soc 2006; 3: 75-80.

16. 蜂須賀康己, 魚本昌志, 波平浩吉, 竹内悦子, 久保克仁. 急性膿胸に対する胸腔鏡下手術一当院における 14 例の 検討一. 気管支学 2006; 28: 271-7.

17. 松岡隆久, 今西直子, 長井信二郎, 松岡勝成, 植田充宏, 宮本好博. 市中発生の急性膿胸に対する胸腔鏡下膿胸掻 爬術 100 例の検討. 日呼外会誌 2015; 29:572-5.

18. 前田 亮, 磯和理貴, 菊地柳太郎. 当院における急性膿胸 に対する胸腔鏡下手術の検討. 日呼外会誌 2007; 21:8716.

\title{
Factors influencing postoperative hospitalization period after thoracoscopic surgery for acute empyema
}

\author{
Eiji Miyahara, Yukari Kawasaki, Atsuo Kimura, Tsuneo Okumichi \\ Department of Thoracic Surgery, Yoshijima Hospital
}

The primary treatment of acute empyema involves drainage and the administration of antibiotics. Debridement and drainage using thoracoscopic surgery were performed in 22 patients with acute empyema that did not respond to thoracic drainage and antibiotic therapy. We evaluated the factors influencing the postoperative hospitalization period (PHP) after thoracoscopic surgery for acute empyema. There was no significant difference in PHP in the presence or absence of a drinking history, preoperative complications, preoperative drainage, or a positive or negative bacterial culture. Moreover, there were no significant correlations among the age, BMI, smoking index, operative time, blood loss, and PHP. When albumin was less than $2.5 \mathrm{~g} / \mathrm{dL}$ before and one week after surgery, PHP was significantly longer than that in cases with a higher albumin level. There was a positive correlation between the period from symptom onset to surgery, and from medical institution visit to consulting our hospital and PHP. Patients with less than 23 days from symptom onset to surgery or with less than 15 days from medical institution visit to consulting our hospital showed a significant reduction in PHP compared with patients who took longer to visit the hospital. In the case of a diagnosis of acute empyema, early consultation with a surgical specialist will decrease PHP. 